\title{
An assessment of the potential for non-plantation biomass resources in selected Asian countries for 2010
}

\author{
S.C. Bhattacharya ${ }^{\mathrm{a}, *}$, P. Abdul Salam ${ }^{\mathrm{a}}$, Hu Runqing ${ }^{\mathrm{b}}$, H.I. Somashekar ${ }^{\mathrm{c}}$, \\ D.A. Racelis ${ }^{\mathrm{d}}$, P.G. Rathnasiri ${ }^{\mathrm{e}}$, Rungrawee Yingyuad $^{\mathrm{f}}$ \\ ${ }^{a}$ Energy Field of Study, School of Environment, Resources and Development, Asian Institute of Technology, \\ P.O. Box 4, Klongluang, Pathumthani 12120, Thailand \\ ${ }^{\mathrm{b}}$ Energy Research Institute, National Development and Reform Commission, 1415 B, Guohong Dasha, Muxidi Beilli, \\ Xicheng District, Beijing 100038, China \\ ${ }^{\mathrm{c}}$ Centre for Sustainable Technologies, Indian Institute of Science, Bangalore, India \\ ${ }^{\mathrm{d}}$ Institute of Renewable Natural Resources, College of Forestry and Natural Resources, University of the Philippines Los Baños, College, \\ Laguna, Philippines \\ ${ }^{\mathrm{e}}$ University of Moratuwa, Katubedda, Moratuwa, Sri Lanka \\ ${ }_{\mathrm{f}}^{\mathrm{f}}$ Bureau of Energy Research, Department of Alternative Energy Development and Efficiency, Thailand
}

\begin{abstract}
This paper presents a synthesis of assessment of the energy potential of non-plantation biomass resources in five Asian countries - China, India, Philippines, Sri Lanka and Thailand, and is based on the detailed national-level studies carried out in these countries under the Asian Regional Research Programme in Energy, Environment and Climate (ARRPEEC). The national level studies were undertaken to estimate the energy potential of: (i) primary residues, (ii) secondary and processing residues (iii) animal manure, (iv) municipal solid wastes (MSW), (v) fuelwood released through efficiency improvement and substitution by other fuels. The sustainable potential of non-plantation biomass resources in 2010 in China, India, Philippines, Sri Lanka and Thailand is estimated to be about 8.90, 8.77, 0.97, 0.14 and $0.82 \mathrm{EJ}$, respectively; the potential is estimated to be about $17,45,34,33$, and $14 \%$ of the projected total energy consumption in 2010 , respectively, in the countries.
\end{abstract}

Keywords: Conservation; Energy potential; Non-plantation biomass; Residues; Sustainable energy

\footnotetext{
*Corresponding author. Tel.: + 6625245403 ; fax: + 6625245439

E-mail address: bhatta@ait.ac.th (S.C. Bhattacharya).
} 


\section{Nomenclature}

$A$ fraction of MSW that is paper and textiles

$\mathrm{ABP}_{\text {manure }}$ amount of biogas from recoverable manure $\left(\mathrm{Nm}^{3} \mathrm{yr}^{-1}\right)$

ADt air dry metric tonne of pulp ( $t$ )

$\mathrm{AH}$ annual harvest of the crop or product (t)

ARG amount of a residue generated annually $\left(\mathrm{t} \mathrm{yr}^{-1}\right)$

$B$ fraction of MSW that is garden waste, park waste or other non-food organic waste

$B_{\mathrm{o}} \quad$ methane producing capacity of wastewater $\left(\mathrm{kg} \mathrm{CH}_{4} \mathrm{~kg}^{-1} \mathrm{COD}\right)$

BOD biological oxygen demand

$C$ fraction of MSW that is food waste

COD chemical oxygen demand $\left(\mathrm{kg} \mathrm{m}^{-3}\right)$

$D$ fraction of MSW that is wood or straw

DM amount of dry matter $\left(\mathrm{kg} \mathrm{head}^{-1} \mathrm{day}^{-1}\right)$

DMR amount of dry matter recoverable from a type of animal manure $\left(\mathrm{kg} \mathrm{DM} \mathrm{yr}^{-1}\right)$

DOC degradable organic content (\%)

$\mathrm{EP}_{\mathrm{LFG}}$ energy potential of LFG $\left(\mathrm{J} \mathrm{yr}^{-1}\right)$

$\mathrm{EP}_{\text {manure }}$ energy potential of the recoverable manure $\left(\mathrm{J} \mathrm{yr}^{-1}\right)$

$E P_{\text {residue }}$ total energy potential of residue $\left(\mathrm{J} \mathrm{t}^{-1}\right)$

$\mathrm{EP}_{\text {wastewater }}$ energy potential of wastewater $\left(\mathrm{J} \mathrm{yr}^{-1}\right)$

EUF energy use factor (dimensionless)

FAS fraction of wastewater treated in anaerobic systems

FCD fraction of carbon dissimilated as $\mathrm{CH}_{4}$ in LFG $\left(0.5 \mathrm{~kg} \mathrm{C}\right.$ as $\mathrm{CH}_{4} \mathrm{~kg}^{-1} \mathrm{C}$ in LFG) (dimensionless)

FCS fraction of fuelwood consumption that can be saved (dimensionless)

FDDOC fraction dissimilated DOC (dimensionless)

FDOC fraction of degradable organic carbon (DOC) in MSW (dimensionless)

FL fraction of MSW land filled (dimensionless)

FR fraction of animal manure recoverable

FW amount of fuelwood consumed in industrial sector $(\mathrm{t})$
$\mathrm{FW}_{\mathrm{ds}}$ potential of fuelwood released in domestic sector $(\mathrm{t})$

$\mathrm{FW}_{\text {is }}$ potential of fuelwood released in industrial sector $(\mathrm{t})$

$\mathrm{FW}_{\mathrm{ts}}$ amount of fuelwood used in traditional stoves $(\mathrm{t})$

$G_{j k} \quad$ fuelwood released through substitution by $j$ fuel in end-use $k(\mathrm{~kg})$

$\mathrm{LHV}_{\text {biogas }}$ lower heating value of biogas $\left(\mathrm{Jm}^{-3}\right)$ $\mathrm{LHV}_{\mathrm{CH}_{4}}$ lower heating value of $\mathrm{CH}_{4}$ $\left(\mathrm{J} \mathrm{kg}^{-1} \mathrm{CH}_{4}\right)$

$\mathrm{LHV}_{\mathrm{FW}}$ lower heating value of fuelwood $\left(\mathrm{J} \mathrm{kg}^{-1}\right)$

$\mathrm{LHV}_{j}$ lower heating value of biomass substitute fuel $j\left(\mathrm{~J} \mathrm{~kg}^{-1}\right)$

$\mathrm{LHV}_{\text {residue }}$ lower heating value of residue $\left(\mathrm{J} \mathrm{t}^{-1}\right)$

$\mathrm{M}_{\mathrm{CH}_{4}}$ methane generation potential $\left(\mathrm{kg} \mathrm{yr}^{-1}\right)$

MSW total MSW generated $\left(\mathrm{kg} \mathrm{yr}^{-1}\right)$

NA number of animals

RPR residue production ratio

SAF surplus availability factor (dimensionless)

$S_{j k} \quad$ amount of substitute fuel $j$ used in place of fuelwood for end-use $k(\mathrm{~kg})$

$T$ temperature $\left({ }^{\circ} \mathrm{C}\right)$

VS fraction of volatile solids in dry matter ( $\left.\mathrm{kg} \mathrm{VS} \mathrm{kg}^{-1} \mathrm{DM}\right)$

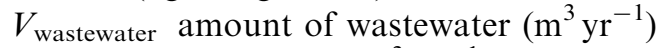

$Y_{\text {biogas }}$ biogas yield $\left(\mathrm{Nm}^{3} \mathrm{~kg}^{-1} \mathrm{VS}\right)$

$\eta_{\text {imp }} \quad$ efficiency of improved cook stove (\%)

$\eta_{j k} \quad$ efficiency of using fuelwood substitute fuel $j$ in the end use $k(\%)$.

$\eta_{k} \quad$ efficiency of using fuelwood in the enduse $k(\%)$

$\eta_{\text {trad }} \quad$ efficiency of traditional cook stove (\%)

Anaerobic digestion a biological process used to decompose organic compound in the absence of oxygen

Biological oxygen demand (BOD) the amount of carbon that is aerobically biodegradable

Chemical oxygen demand (COD) the total material that can be oxidized (both biodegradable and non- biodegradable)

Dry matter the matter left after removal of moisture content of animal manure. It may be obtained as the weight loss on heating to a temperature of $105^{\circ} \mathrm{C}$ 
Energy use factor the fraction of residue presently being used as fuel

Residue production ratio the ratio of the amount of residue generated to the total amount of agricultural product produce
Surplus availability factor the ratio of surplus (presently wasted) amount to the amount of residue generated

Volatile solids the organic fraction of dry matter in waste

\section{Introduction}

The term biomass refers to all organic materials that originate from living organisms e.g. wood, agricultural residues, animal manure etc. Biomass sources are therefore diverse. Biomass has always been a major source of energy for mankind, and accounts for about $14 \%$ of the world's total energy supply.

In recent years interest in biomass as a modern energy source, especially for electricity generation has been growing worldwide. The main reasons for this include: (i) recent developments relating to the conversion technology and biomass production that have made bioenergy competitive with fossil fuel based energy generation in some situations, (ii) environmental benefits provided by the modern biomass energy, (iii) enhancement of energy security and diversity of energy supply, (iv) employment generation and rural development, and (v) restoration of degraded lands as a result of plantation and possibility of increase in biodiversity.

Although trees and plantations are the main sustainable sources of biomass, a number of other sources of biomass also exist. These include agricultural residues, animal manure, municipal solid wastes (MSW), industrial wastewater etc. In addition to the above sources, there are indirect means of generation of biomass energy, e.g. (i) saving of fuelwood from substitution by other fuels; as an example, switching from fuelwood to LPG for cooking reduces the consumption of fuelwood for cooking, and (ii) saving of fuelwood through efficiency improvements of current energy systems. These indirect sources of biomass too can be utilized for modern bioenergy applications.

A regional programme titled "Asian Regional Research Programme in Energy, Environment and
Climate (ARRPEEC)" was launched by the Swedish International Development Cooperation Agency (SIDA) and the Asian Institute of Technology (AIT) in 1994 to address the energy-environment-climate (EEC) related issues in selected Asian countries. An assessment of sustainable energy potential of non-plantation biomass resources was carried out in the phase II of the biomass project of ARRPEEC.

This paper presents a synthesis of assessment of sustainable primary energy potential of nonplantation biomass resources in five Asian countries-China, India, Philippines, Sri Lanka and Thailand; the resources considered are agricultural residues, animal manure, municipal solid waste, wastewater and black liquor. It may be noted that the resources are normally utilized inefficiently and can potentially provide significant additional energy services if used efficiently. In addition to the above non-plantation resources, the paper also considers fuelwood that can be potentially released through efficiency improvement of existing energy systems and through substitution by other fuels. Detailed studies on these countries are presented in the other papers of this special journal issue.

\section{Methodologies for assessment of sustainable national biomass resources potential}

This section presents the methodologies used to assess the potential of the different resources considered in this study; these can be categorized into: (i) primary residues (paddy straw, sugarcane top, maize stalks, coconut empty bunches and frond, palm oil frond and male bunches etc.) and, (ii) secondary residues (paddy husk, bagasse, maize cob, coconut shell, coconut husk, coir dust, 
saw dust, palm oil shell, fiber and empty bunches, wastewater, black liquor etc.), (iii) animal manure, (iv) municipal solid wastes (MSW), and (v) fuelwood released through efficiency improvement and substitution by other fuels.

\subsection{Primary residues}

The term agricultural residue is used to describe all the organic materials which are produced as the by-products from harvesting and processing of agricultural crops. These residues can be further categorized into primary residues and secondary residues. Agricultural residues, which are generated in the field at the time of harvest are defined as primary or field based residues (e.g. rice straw, sugar cane tops), whereas those co-produced during processing are called secondary or processing based residues (e.g. rice husk, bagasse). Availability of primary residues for energy application is usually low since collection is difficult and they have other uses as fertilizer, animal feed etc. However secondary residues are usually available in relatively large quantities at the processing site and may be used as captive energy source for the same processing plant involving no or little transportation and handling cost.

\subsubsection{Energy potential of the residues}

The estimation of residue generated can be calculated based on the residue to product ratio (RPR). To estimate the potential of deriving additional energy from a residue, it is important to establish the present utilisation pattern of the residue [1].

$$
\begin{aligned}
& \mathrm{ARG}=\Sigma(\mathrm{RPR} \times \mathrm{AH}), \\
& \mathrm{EP}_{\text {residue }}=\mathrm{ARG} \times(\mathrm{SAF}+\mathrm{EUF}) \times \mathrm{LHV}_{\text {residue }} .
\end{aligned}
$$

\subsubsection{Fuel characteristics}

Moisture content of residues normally varies widely at different stages of harvesting and storage. The moisture content of a residue influences its asfired heating value and should be known.

Ultimate analysis, particularly carbon and nitrogen contents on dry basis are important for estimating greenhouse gas (GHG) emissions.
Also, costs of agricultural residues, including collection and transportation costs, are needed to estimate the cost of final energy from these fuels. A review of RPR values at different moisture content and lower heating values (LHVs) for different residues were carried out by Bhattacharya et al. [2]. The RPR values reported by them can be used for estimating energy potential of agricultural residues; however, country-specific RPR and LHV values should be used wherever possible.

\subsection{Secondary residues}

The energy potential of certain secondary residues, e.g. bagasse, rice husk, cob etc., also could be estimated using the methodologies used for the primary residues. The methodologies used for estimating energy potential of wastewater and black liquor are given below.

\subsubsection{Wastewater and palm oil mill effluents (POME)}

Large amount of wastewater is discharged from various industries under two broad categories: inorganic and organic. Wastewater from organic industries, such as, wood processing, pulp and paper, plastic, soap and synthetic detergent, tanneries and leather, oil refineries, textile, pharmaceutical and cosmetic, etc., are considered in this study.

Each industry requires different methods for wastewater treatment depending on the characteristics and amount of wastewater. These methods can be classified as: (i) physical unit processes (screening, mixing, flocculation, sedimentation, flotation, filtration), (ii) chemical unit processes (precipitation, adsorption, disinfection), and (iii) biological unit processes (aerobic processes, anaerobic processes, anoxic denitrification).

There are various combinations of these operations and processes to treat wastewater. In the present study, potential of $\mathrm{CH}_{4}$ generation from wastewater from organic industries through anaerobic digestion is estimated. The principal factor in determining the $\mathrm{CH}_{4}$ generation potential of wastewater is the amount of degradable organic material in the wastewater. Common parameters used to measure the organic content of the 
wastewater are the Biological Oxygen Demand (BOD) and Chemical Oxygen Demand (COD).

\subsubsection{Wastewaters suitable for anaerobic diges-} tion. Anaerobic digestion is economical for medium and high strength wastewater (having COD in excess of $1.5 \mathrm{~kg} \mathrm{~m}^{-3}$ ). Low strength wastewater at temperatures below $12^{\circ} \mathrm{C}$ is not competitive to aerobic treatment [3]. Wastewater from food processing industries is normally suitable for anaerobic digestion because they contain high concentration of organic matter and low levels of inhibitors. Table 1 shows the details of the industries which produce wastewater suitable for anaerobic digestion. Table 2 shows the performance characteristics of different types of anaerobic reactors.

\subsubsection{Estimation of energy potential of waste-} water. Treatment of wastewater under anaerobic conditions results in $\mathrm{CH}_{4}$ production. The extent of $\mathrm{CH}_{4}$ production depends primarily on the following factors [4]: (i) wastewater characteristics, (ii) handling systems, (iii) temperature, and (iv) BOD and COD.

For any given type of wastewater, the total energy generation potential of wastewater through anaerobic treatment is given by

$$
\begin{aligned}
\mathrm{EP}_{\text {wastewater }}= & V_{\text {wastewater }} \times \mathrm{COD} \times \mathrm{FAS} \times B_{\mathrm{o}} \\
& \times \mathrm{LHV}_{\mathrm{CH}_{4}} .
\end{aligned}
$$

Table 3 shows the values of COD $\left(\mathrm{kg} \mathrm{m}^{-3}\right)$ and methane producing capacity $\left(B_{\mathrm{o}}\right)$ of different types of wastewater $[5,6]$. The theoretical maximum value of $B_{\mathrm{o}}$ is $0.25 \mathrm{~kg} \mathrm{CH}_{4} \mathrm{~kg}^{-1} \mathrm{COD}$.

\subsubsection{Black liquor}

One of the waste streams of pulp and paper industry is black liquor, which is dark brown solution from cooking and washing of pulp that contains dissolved organic matter, such as lignin and resins, and inorganic matter.

Black liquor generally contains $13 \%$ to $17 \%$ dissolved solids. The black liquor has to be concentrated to above $60 \%$ solids before it will burn without supplemental fuel [7].

The concentration of black liquor is normally carried out in multiple effect evaporators using low pressure steam extracted from the turbine. Evaporators raising solids concentration to $65 \%$ and higher are known as concentrators.

The chemical recovery boiler is a steam generator using black liquor as fuel. The black liquor is burned at solid concentration of about $65 \%$ and efficiency of the boiler is about $65 \%$.

2.2.2.1. Composition of black liquor. The composition of black liquor depends on the composition of inorganic chemicals charged, wood species, and pulp yield. The wood species used for pulping can be identified as one of the major factors which determines black liquor composition. Black liquor

Table 1

Industries producing wastewater suitable for anaerobic digestion

\begin{tabular}{lll}
\hline Industries & Biological oxygen demand (BOD) $\left(\mathrm{kg} \mathrm{m}^{-3}\right)$ & Wastewater amount \\
\hline Slaughterhouse \& meat processing & 32 (blood and tank water) & $300-2000 \mathrm{~m}^{3}$ per slaughtered animal \\
Starch & $6-30$ (potatoes) & $15-25 \mathrm{~m}^{3} \mathrm{t}^{-1}$ potatoes \\
& $6-10$ (Grain) & $9-11 \mathrm{~m}^{3} \mathrm{t}^{-1}$ grain \\
Brewery & $0.01-25$ (press liquor) & $15 \mathrm{~m}^{3} \mathrm{~m}^{-3}$ beer (without malting) \\
Distillery & 28.7 (molasses) & $10 \mathrm{~m}^{3} \mathrm{t}^{-1}$ grain $^{3}$ \\
Fruit \& vegetable & $0.38-4.70$ (peas) & $2-14 \mathrm{~m}^{3} \mathrm{t}^{-1}$ vegetable product \\
Cannery & $0.18-3.88$ (tomatoes) & $1-3 \mathrm{~m}^{3} \mathrm{t}^{-1}$ fresh fruit \\
Cane sugar & $2-3$ & \\
Milk processing & 1.89 (process water) & $2-6 \mathrm{~m}^{3} \mathrm{~m}^{-3}$ milk \\
Coffee & 47 (pulp), 1.25-2.22 (fermentation waste) & $15.1 \mathrm{~m}^{3} \mathrm{t}^{-1}$ fruit \\
Bakery & $3-5$ & $100-125 \mathrm{~m}^{3} \mathrm{t}^{-1}$ pulp \\
Pulp & & \\
\hline
\end{tabular}


Table 2

Performance of anaerobic processes

\begin{tabular}{lllll}
\hline Process & $\begin{array}{l}\text { Chemical oxygen } \\
\text { demand (COD) }\left(\mathrm{kg} \mathrm{m}^{-3}\right)\end{array}$ & $\begin{array}{l}\text { Hydraulic } \\
\text { retention time (h) }\end{array}$ & $\begin{array}{l}\text { Organic loading (kg } \\
\left.\text { COD m } \text { day }^{-1}\right)\end{array}$ & COD removal (\%) \\
\hline $\begin{array}{l}\text { Anaerobic contact (AC) reactor } \\
\text { Upflow anaerobic sludge blanket }\end{array}$ & $1.5-5.0$ & $2-10$ & $0.48-2.40$ & $75-90$ \\
$\begin{array}{l}\text { (UASB) reactor } \\
\text { Anaerobic filter (AF) reactor }\end{array}$ & $10.0-20.0$ & $4-12$ & $4.00-12.01$ & $75-85$ \\
\hline
\end{tabular}

Table 3

Maximum methane producing capacity $\left(B_{\mathrm{o}}\right)$ of wastewater

\begin{tabular}{llll}
\hline Type of waste water & $\mathrm{COD}\left(\mathrm{kg} \mathrm{m}^{-3}\right)$ & $B_{\mathrm{o}}\left(\mathrm{kg} \mathrm{CH}_{4} \mathrm{~kg}^{-1} \mathrm{COD}\right)$ & References \\
\hline Paper mill & $1.6-2.0$ & 0.20 & Hack [5] \\
Tissue factory & $0.9-2.0$ & 0.18 & 0.15 \\
Paper mill & 2.0 & 0.20 \\
Paper mill & 2.5 & 0.19 \\
Pulp mill & 20.0 & 0.20 \\
Paper mill & $2.5-3.5$ & 0.19 & Shick and Alan [6] \\
Board mill & 7.0 & 0.20 & \\
Sweat whey & 58.5 & 0.21 \\
Sweat whey permeate & 28.7 & 0.21 & 0.24 \\
Sweat whey permeate & 62.1 & 0.20 & \\
Acid whey permeate & 55.1 & 0.25 & \\
Wheat starch wastewater & 35.2 & 0.22 \\
Molasses & $8.7-9.5$ & 0.20 & \\
Whey permeate & 13.2 & 0.20 & \\
\end{tabular}

composition in terms of ultimate analysis is given in Table 4 for some wood species.

Typical black liquor solids (BLS) contain about $35-40 \%$ of volatile matter, $10-15 \%$ of fixed carbon, and $35-40 \%$ of Ash.

\subsubsection{Calorific value. Black liquor releases} heat when burning in the recovery boiler furnace. Typically softwood black liquors have heating values in the range of $14.6-14.9 \mathrm{MJ} \mathrm{kg}^{-1}$ with hardwood liquors in the range of 13.5$13.9 \mathrm{MJ} \mathrm{kg}^{-1}$ [8].

\subsubsection{Estimation of energy potential of black} liquor. In a typical new mill [9]:

Energy associated with steam produced from black liquor $=16.5 \mathrm{GJ} \mathrm{ADt}^{-1}$.
Table 4

Ultimate analysis of black liquor based on wood species

\begin{tabular}{lllllll}
\hline Type of black liquor & \multicolumn{4}{l}{ Ultimate analysis (wt\% dry) } \\
\cline { 2 - 7 } & $\mathrm{C}$ & $\mathrm{H}$ & $\mathrm{O}$ & $\mathrm{N}$ & $\mathrm{S}$ & $\mathrm{Cl}$ \\
\hline From straw pulping & 45.8 & 4.49 & 25.8 & 1.29 & 0.55 & 0.018 \\
From spruce wood & 34.2 & 4.1 & 38 & 0.2 & 4 & 0.2 \\
From eucalyptus & 63.9 & 6.2 & 25.8 & 0.8 & 1.7 & - \\
\hline
\end{tabular}

Source: http://www.ecn.nl/cgi-ecn/ecn/phyllis.pl?cgi-bin/DataTable.asp.

Energy associated with steam consumption for evaporation of black liquor $=4.2 \mathrm{GJ} \mathrm{ADt}^{-1}$. Energy associated with steam consumption for process (except black liquor evaporation) and 
power generation (i.e. net energy from black liquor) $=12.3 \mathrm{GJ} \mathrm{ADt}^{-1}$.

Input energy equivalent of net energy from black liquor $=12.3 / 0.90=13.7 \mathrm{GJ} \mathrm{ADt}^{-1}$.

(Efficiency of fossil fuel fired boiler based on LHV is assumed as $90 \%$ )

\subsection{Animal manure}

Animal manure is principally composed of organic material, moisture and ash. Decomposition of animal manure can occur either in an aerobic or anaerobic environment. Under aerobic conditions, $\mathrm{CO}_{2}$ and stabilised organic materials (SOM) are produced. Under anaerobic conditions, $\mathrm{CH}_{4}, \mathrm{CO}_{2}$, and SOM are produced. Since the quantity of animal manure produced annually can be substantial, the potential for $\mathrm{CH}_{4}$ production and hence energy potential of animal manure is significant.

Energy potential of recoverable animal manure is estimated by [10]:

$\mathrm{EP}_{\text {manure }}=\mathrm{ABP}_{\text {manure }} \times \mathrm{LHV}_{\text {biogas }}$,

where,

$$
\begin{aligned}
& \mathrm{ABP}_{\text {manure }}=\Sigma\left(\mathrm{DMR} \times \mathrm{VS} \times Y_{\text {biogas }}\right), \\
& \mathrm{DMR}=\mathrm{DM} \times \mathrm{NA} \times \mathrm{FR} \times 365 .
\end{aligned}
$$

The dung production from animals depends on factors such as body weight of the animal, type and quality of the feed, physiological state etc. Accessibility of the dung is an important factor, particularly where livestock are range-fed, and consequently the dung is not easily accessible. When the animals are entirely stall-fed, all the dung is produced in the shed. A preliminary estimate of energy potential of animal manure was reported by Bhattacharya et al. [10]. Amount of dry matter from an animal, recoverable fraction of animal manure, volatile solid fraction, and biogas yield values reported by them could be used for estimating energy potential of animal manure; it is recommended that country specific values should be used wherever possible.

\subsection{Municipal solid wastes (MSW)}

Municipal solid waste (MSW) is the solid waste generated by households, commercial establishments, and institutions etc. [11]. The waste consists of perishable organic wastes, glass, paper, plastics, metals etc. Generally, MSW does not include construction or demolition debris or automobile scrap. Tables 5 and 6 show some data regarding the physical properties of MSW.

Though details vary from city to city, the following generalizations apply to the majority of cities in developing countries.

- Per capita waste generation rate in developing countries depends on the level of income of the households, which can be categorized into two groups i.e., (i) lower income group with waste generation of $0.25-0.60 \mathrm{~kg}_{\text {capita }}{ }^{-1} \mathrm{day}^{-1}$ and, (ii) middle income group with waste generation of $0.5-0.85 \mathrm{~kg} \mathrm{capita}^{-1} \mathrm{day}^{-1}$. This may be compared with European countries where the waste generation ranges from 0.70 to $0.85 \mathrm{~kg} \mathrm{capita}^{-1} \mathrm{day}^{-1}$, and for United States it is $1.25-1.80 \mathrm{~kg} \mathrm{capita}^{-1} \mathrm{day}^{-1}$.

- The cost of present MSW handling systems is very high. Some cities in developing countries spend a third or more of their municipal budget on waste collection and disposal.

Table 5

\begin{tabular}{|c|c|c|c|c|c|c|c|}
\hline Location & $\begin{array}{l}\text { Vegetable \& } \\
\text { putrescible }\end{array}$ & $\begin{array}{l}\text { Paper \& paper } \\
\text { boards }\end{array}$ & Plastics & Metals \& glass & Other organics & $\begin{array}{l}\text { Miscellaneous } \\
\text { in-organics }\end{array}$ & Fines \& ash \\
\hline US cities & 26 & 41 & 6 & 17 & 8 & 2 & - \\
\hline $\begin{array}{l}\text { Jakarta- } \\
\text { Indonesia }\end{array}$ & 74 & 8 & 6 & 4 & 8 & & \\
\hline Port of Spain & 44 & 26 & 3 & 18 & 6 & - & 3 \\
\hline Delhi-India & 57 & 6 & 3 & 6 & 5 & - & 23 \\
\hline
\end{tabular}

Percentage of composition of MSW 
Table 6

Density and moisture content of MSW

\begin{tabular}{llll}
\hline Location & Density $\left(\mathrm{kg} \mathrm{m}^{-3}\right)$ & Moisture (\%) & Remarks \\
\hline US cities & 100 & 25 & Includes high percentage of paper and empty containers \\
Europe & 150 & 60 & Includes low percentage of paper \& high fraction of wet garbage \\
Developing countries & $250-350$ & 60 & Includes high \% of street sweeping \\
Some South Asian cities & Up to 500 & &
\end{tabular}

- Householders, waste collectors and scavengers at dumps remove some of re-usable or recyclable items from waste,

- The use of sanitary landfill is very limited due to the high costs.

- Most of the wastes are simply dumped on the open land, thus leading to environmental and health hazards like the odor, smoke, ground water pollution, and spread of diseases by flies, rats, animals or human scavengers.

The seriousness of problems posed by MSW clearly justifies careful consideration of all waste to energy options.

\subsubsection{Calorific value}

Waste to energy systems have been developed in the US and Europe to burn solid wastes with high calorific value resulting from large fractions of paper and other dry combustibles; the figures are $10.5 \mathrm{MJ} \mathrm{kg}^{-1}$ for US and $7.5 \mathrm{MJ} \mathrm{kg}^{-1}$ for Europe. In developing countries, the calorific value of MSW is much lower due to high moisture and low combustible content. In Indian medium sized cities the range is between 3.36 and $4.62 \mathrm{MJ} \mathrm{kg}^{-1}$, while that in case of larger Indian cities is 4.62 and $6.30 \mathrm{MJ} \mathrm{kg}^{-1}$.

\subsubsection{Determination of $M S W$ generation}

There are several methods to estimate MSW generation $[12,13]$. In this paper, MSW generation $\left(\mathrm{kg} \mathrm{yr}^{-1}\right)$ is obtained by multiplying the urban population of a country by the MSW generation rate $\left(\mathrm{kg} \mathrm{capita}^{-1} \mathrm{yr}^{-1}\right)$.

Country specific MSW generation rate should be used for the estimation of total MSW genera-
Table 7

MSW generation rate for selected Asian countries

\begin{tabular}{ll}
\hline Country & $\begin{array}{l}\text { MSW generation rate } \\
\left(\mathrm{kgcapita}^{-1} \mathrm{day}^{-1}\right)\end{array}$ \\
\hline India & 0.52 \\
China & 1.04 \\
Malaysia & 0.71 \\
Philippines & 0.50 \\
Sri Lanka & 0.75 \\
Thailand & 1.09 \\
\hline
\end{tabular}

tion. The generation rate estimated by Homez [14] is given in Table 7 .

\subsubsection{Energy from $M S W$ through in situ anaerobic digestion in a landfill}

In developed countries, projects have been implemented to recover and use gas generated from sanitary landfills through the anaerobic digestion of MSW; the gas is often called landfill gas (LFG). The gas mainly consists of methane and carbon dioxide. The feasibility of landfill gas is greatly influenced by the waste collection, scavenging and waste disposal practices and by the composition of the waste [15].

\subsubsection{Landfill gas ( $L F G$ ) recovery}

For LFG recovery, the wastes filled in land should be covered with a thick layer of soil to prevent the escape of the gas and infiltration of significant quantities of $\mathrm{O}_{2}$ into the landfill. The depth of cover depends on soil type and climate. A clay or plastic liner is necessary to avoid leachate contaminating the ground water. A gas collection system consisting of wells, perforated plastic pipes and blowers is used to collect LFG. 
The methane content of the gas is in the range of $30-65 \%$. Calorific value depends on the methane content and ranges from 8.7 to $20.6 \mathrm{MJ} \mathrm{m}^{-3}$.

\subsubsection{Prediction of $L F G$ volume and quality}

The potential of recoverable gas at a landfill is highly variable and hard to predict. The reason for prediction difficulty is that amount, age and composition of the waste at a site are not always well known. Records of the landfill are on volume basis and gas generation models work on weight basis. The amount and rate of gas generation from a kilogram of refuse is also highly variable.

There are estimates suggesting that all gas is produced within 7 years. But some reports suggest that the gas is generated at lower rates over a much longer period of time.

The energy potential of LFG is given by

$\mathrm{EP}_{\mathrm{LFG}}=\mathrm{M}_{\mathrm{CH}_{4}} \times \mathrm{LHV}_{\mathrm{CH}_{4}}$.

The methane generation from managed landfill sites could be estimated by [4]

$$
\begin{aligned}
\mathrm{M}_{\mathrm{CH}_{4}}= & \mathrm{MSW} \times \mathrm{FL} \times \mathrm{FDOC} \times \mathrm{FDDOC} \\
& \times \mathrm{FCD} \times 16 / 12 .
\end{aligned}
$$

Degradable organic carbon (DOC) content is based on the composition of waste, and can be calculated from a weighted average of the carbon content of various components of the waste stream. A set of default DOC values for different wet (or fresh) wastes are given in Table 8 [3]. Using the values in Table 8, the fraction of degradable organic carbon (FDOC) content of a country's waste could be calculated as shown below:

$\mathrm{FDOC}=0.4(A)+0.17(B)+0.15(C)+0.30(D)$.

Table 9 shows the percentage of DOC of fresh MSW estimated [14] for different waste streams of different Asian countries.

The fraction of dissimilated DOC is the portion of DOC that is converted to landfill gas. Estimate of how much carbon may be dissimilated can be obtained theoretically assuming that it varies only with the temperature in the anaerobic zone of a landfill [4]:

$\mathrm{FDDOC}=0.014 T+0.28$.
Table 8

Default degradable organic carbon (DOC) values for major waste streams

\begin{tabular}{ll}
\hline Waste stream & $\begin{array}{l}\text { Percent DOC } \\
\text { (by weight) }\end{array}$ \\
\hline Paper and textiles & 40 \\
Garden and park waste, and other (non- & 17 \\
food) organic putrescibles & 15 \\
Food waste & 30 \\
Wood and straw waste & \\
\hline
\end{tabular}

Table 9

Degradable organic carbon (DOC) of MSW (\% of fresh MSW)

\begin{tabular}{lccccr}
\hline Country & Paper & Textile & Wood & Food & Total \\
\hline India & 0.53 & 0.71 & 5.71 & 8.45 & 16.90 \\
China & 2.29 & 0.18 & 0.93 & 5.50 & 7.96 \\
Malaysia & 7.08 & 0.51 & 4.39 & 7.61 & 18.15 \\
Philippines & 3.91 & 0.27 & 2.20 & 5.65 & 13.23 \\
Sri Lanka & 3.52 & 0.11 & 0.06 & 9.84 & 13.91 \\
Thailand & 5.10 & 1.46 & 4.26 & 6.48 & 17.09 \\
\hline
\end{tabular}

If one assumes that the temperature in the anaerobic zone of a landfill site remain constant at about $35^{\circ} \mathrm{C}$, regardless of ambient temperature, this method yields a figure of 0.77 for fraction of dissimilated DOC [4].

\subsection{Fuelwood released through efficiency improvement and substitution by other fuels}

\subsubsection{Fuelwood released through efficiency improvement}

In the household sector, large amounts of fuelwood are consumed, normally in inefficient traditional stoves, for cooking and space heating purposes. Many small-scale rural industrial enterprises use fuelwood for process heating and drying of the final products. These enterprises normally use traditional technologies which are inefficient in nature. These industries include: (i) agricultural and food processing (rubber and coconut processing, fish and meat drying etc.), (ii) metal processing and mineral based activities (brick making, lime burning, pottery, foundry, etc.), (iii) forest products (Bamboo and cane, distilleries, timber drying, etc.), and (iv) service sector (road tarring, catering services etc.). In this 
section, methodologies for estimation of fuelwood released through efficiency improvement are considered.

\subsubsection{Potential of fuelwood release from domes-} tic sector. Traditional cook stoves available in the developing countries have efficiencies in the range of $5-15 \%$. The types of cook stoves available are basically classified into two types: (i) fuelwood using, and (ii) charcoal using.

Potential of fuelwood released if all the traditional cook stoves are replaced by improved cook stoves is estimated as [16]:

$\mathrm{FW}_{\mathrm{ds}}=\mathrm{FW}_{\mathrm{ts}} \times\left(\eta_{\mathrm{imp}}-\eta_{\mathrm{trad}}\right) / \eta_{\mathrm{imp}}$.

2.5.1.2. Potential of fuelwood release from industrial sector. The energy efficiency improvement of the following devices are considered in this study: (i) bakery ovens, (ii) wood fired boilers, (iii) furnaces, (iv) kilns.

Potential of fuelwood released from industrial sector, due to energy efficiency improvement, is estimated by

$\mathrm{FW}_{\text {is }}=\mathrm{FW} \times \mathrm{FCS}$.

\subsubsection{Potential of fuelwood release from bakery} ovens. Inefficiency of bakery oven is normally due to high excess air and poor distribution and circulation of heat. Actual wood fuel consumption depends on skill of baker, bread type, size and type of oven, type of wood and moisture content of wood. In this study, the fuelwood saving potential through replacement of traditional ovens by improved ovens has been assumed to be $40 \%$ [16].

\subsubsection{Potential of fuelwood release from wood} fired boilers. There are three ways of improving efficiency of wood fired boiler: (i) heat recovery from exhaust flue gases, (ii) reduction of moisture content of wood, and (iii) reduction of excess air for combustion. Fuelwood saving potential of wood fired boilers has been assumed to be $10 \%$ in this study [16].
2.5.2. Fuelwood released through substitution by other fuels

Clean and efficient use of fuelwood in small energy devices, e.g. stoves, is inherently difficult. People therefore normally tend to switch over from fuelwood to better fuels as their purchasing power and economic condition improve. Fuelwood and charcoal could be substituted by LPG, kerosene or electricity. Fuelwood thus substituted by other fuels can be used in larger-scale systems, for example for the generation of electricity. This section considers methodologies to estimate such potential of fuelwood.

Estimation of the amounts of fuelwood that can be released through substitution involves the following steps: (a) determination of the current consumption pattern/level for fuelwood in terms of the following categories; (i) domestic - rural and urban Households (HH), (ii) industrial and commercial, (b) determination of the factors that could affect the rate of substitution. For example, efficiency - in terms of types of fuel and equipment, and (c) generation potential of fuelwood, through substitution is equivalent to sum of the amounts of fuelwood that can be substituted by all fuel types (i.e. LPG, kerosene or electricity) in all kind of end uses (i.e. domestic, industrial or commercial).

It is assumed that the amounts of useful energy delivered before and after substitution are the same:

$G_{j k}=\left(\Sigma S_{j k} \times \eta_{j k} \times \mathrm{LHV}_{j}\right) /\left(\mathrm{LHV}_{\mathrm{FW}} \times \eta_{k}\right)$.

For fuelwood, $G_{j k}$ can be estimated based on assumptions regarding the extent of its substitution by different fuels $(j)$ for different end-uses $k$. The efficiency values should be obtained from literature review. Also additional supply of substitute fuels likely to be available in the future should be obtained from national government plans/estimates.

\section{Energy potential of sustainable biomass resources}

\subsection{Primary and secondary residues}

Table 10 shows the estimated energy potential of primary and secondary residues in the selected 
Table 10

Energy potential of primary and secondary residues in the selected Asian countries (PJ)

\begin{tabular}{|c|c|c|c|c|c|c|c|c|c|c|c|c|c|c|}
\hline \multirow[t]{3}{*}{ Primary and secondary residues } & \multicolumn{14}{|c|}{ Energy potential (PJ) } \\
\hline & \multicolumn{3}{|l|}{ China } & \multicolumn{2}{|l|}{ India } & \multicolumn{3}{|c|}{ Philippines } & \multicolumn{3}{|c|}{ Sri Lanka } & \multicolumn{3}{|c|}{ Thailand } \\
\hline & 1997 & 2005 & 2010 & 1997 & 2010 & 1997 & 2005 & 2010 & 1997 & 2005 & 2010 & 1997 & 2005 & 2010 \\
\hline Paddy straw & 1010 & 924 & 845 & 347 & 532 & 18.5 & 22.7 & 25.6 & 30.26 & 32.73 & 34.29 & 60.3 & 61.1 & 66.6 \\
\hline Paddy husk & & & & & & 45.6 & 54.6 & 61.3 & 4.66 & 5.04 & 5.28 & 66.0 & 70.2 & 72.9 \\
\hline Sugarcane top & & & & 842 & 1443 & & & & 1.45 & 1.45 & 1.45 & 114.5 & 129.2 & 139.3 \\
\hline Maize stalks & & & & 69 & 80 & & & & 0.39 & 0.42 & 0.44 & & & \\
\hline Palm oil—field residues & & & & & & & & & & & & 65.1 & 97.7 & 125.8 \\
\hline Wheat & 1360.1 & 1199.7 & 1167.4 & 115 & 278 & & & & & & & & & \\
\hline Corn & 1684.8 & 2423.8 & 2323.4 & & & & & & & & & & & \\
\hline Beans & 227.2 & 173.6 & 160.5 & & & & & & & & & 13.2 & 13.2 & 13.2 \\
\hline Tubers & 128.9 & 124.4 & 118.2 & & & & & & & & & & & \\
\hline Sorghum & 58.8 & 56.8 & 53.9 & & & & & & & & & 3.84 & 4.49 & 4.95 \\
\hline Coarse grains & 74.4 & 71.8 & 68.2 & & & & & & & & & & & \\
\hline Oil bearing & 348.5 & 422.4 & 384.8 & & & & & & & & & & & \\
\hline Cotton & 111.5 & 115.6 & 105.3 & 750 & 835 & & & & & & & 3.2 & 3.2 & 3.2 \\
\hline Jute & & & & 235 & 88 & & & & & & & & & \\
\hline Bajra & & & & 0 & 18 & & & & & & & & & \\
\hline Red gram & & & & 176 & 145 & & & & & & & & & \\
\hline Gram & & & & 121 & 176 & & & & & & & & & \\
\hline Other pulses & & & & 222 & 215 & & & & & & & & & \\
\hline Ground nut & & & & 284 & 384 & & & & & & & 0.53 & 0.58 & 0.60 \\
\hline Rape seed & & & & 189 & 330 & & & & & & & & & \\
\hline Other oil seeds & & & & 249 & 371 & & & & & & & & & \\
\hline Mulberry & & & & 45 & 50 & & & & & & & & & \\
\hline Coffee + tea & & & & 51 & 59 & & & & & & & & & \\
\hline Coconut empty bunches \& frond & & & & & & & & & & & & 5.45 & 5.45 & 5.45 \\
\hline Cassava & & & & & & & & & & & & 11.0 & 9.63 & 8.88 \\
\hline Bagasse & 232.2 & 77.1 & 80.4 & 720 & 1138 & 141.9 & 166.6 & 182.8 & 2.17 & 2.17 & 2.17 & 90.7 & 102.2 & 110.1 \\
\hline Maize cob & & & & & & & & & 0.09 & 0.10 & 0.10 & 16.3 & 19.5 & 21.8 \\
\hline Palm oil—process residues & & & & & & & & & & & & 19.40 & 29.0 & 37.4 \\
\hline Coconut shell & & & & 300 & 423 & 135.9 & 151.5 & 161.3 & 6.73 & 7.28 & 7.64 & 2.96 & 2.96 & 2.96 \\
\hline Coconut husk & & & & & & & & & 9.24 & 9.98 & 9.37 & 6.7 & 6.7 & 6.7 \\
\hline Coir dust & & & & & & & & & 0.09 & 0.10 & 0.11 & & & \\
\hline Saw dust & & & & & & & & & 3.59 & 3.67 & 3.71 & & & \\
\hline Total & 5236.4 & 5589.1 & 5307.2 & 4715 & 6565 & 341.9 & 395.4 & 431.0 & 58.7 & 62.9 & 64.6 & 479.1 & 557.9 & 619.8 \\
\hline
\end{tabular}

Asian countries. Energy potential of ten crop residues, i.e. rice, wheat, corn, beans, tubers, sorghum, coarse grains, oil bearing, cotton and sugarcane, in China is estimated to be about 5.24, 5.59 and 5.31 EJ in 1997, 2005 and 2010, respectively. In India, straw from rice, wheat and other cereal plants, husk from rice, stalk, cobs, wastes from pulses, ground nut, jute, cotton and other oil seeds, shell from ground nut, sticks from mulberry, twigs and branches from coffee and tea are considered. Among the crops grown in the
Philippines, only three major crops, i.e., rice, coconut and sugarcane, were identified to have large contribution to the country's biomass energy resources; the most common agricultural residues are rice husk, rice straw, coconut husk, coconut shell and bagasse. In case of Sri Lanka, the types of agricultural residues selected for the assessment are rice husk, rice straw, coconut shell, coconut husk, coir dust, bagasse, sugar cane tops, maize stalk and maize cobs. In addition to these sources, sawdust is also included in the assessment since 
it has a considerable potential as an energy source. Ten main agricultural products with high residue potential were studied in Thailand. Those agricultural products are sugar cane, paddy, oil palm, coconut, cassava, maize, groundnut, cotton, soybean and sorghum.

\subsection{Wastewater}

The $\mathrm{CH}_{4}$ producing potential of wastewater depends on the composition and degradability of the wastewater. The theoretical maximum value of methane producing capacity is $0.25 \mathrm{~kg} \mathrm{CH}_{4} \mathrm{~kg}^{-1}$ COD. Actual value of methane producing capacity $\left(B_{\mathrm{o}}\right)$, depends on COD removal efficiency. In China, the wastewater production rate in different sector varies from $0.1-1130 \mathrm{~m}^{3} \mathrm{t}^{-1}$ of product. The COD of wastewater varies from 0.6 to $60 \mathrm{~kg}$ COD $\mathrm{m}^{-3}$ wastewater. The fraction of wastewater treated in aerobic systems is $90 \%$. In case of India, the COD of wastewater was assumed as it varies from 0.3 to $118 \mathrm{~kg} \mathrm{~m}^{-3}$. In Thailand, it was assumed that $B_{\mathrm{o}}$ is $0.194 \mathrm{~kg} \mathrm{CH}_{4} \mathrm{~kg}^{-1} \mathrm{COD}$ which is equivalent to $0.5 \mathrm{~m}^{3}$ of biogas $\mathrm{kg}^{-1}$ of COD and for estimating energy potential the entire wastewater is assumed to be treated by anaerobic systems; the amount of biogas produced is assumed to be $0.5 \mathrm{~m}^{3} \mathrm{~kg}^{-1} \mathrm{COD}$ removed. Energy potential of wastewater in 2010 is estimated to be 102, 200, 0.35 and 7.8 PJ for China, India, Sri Lank and Thailand, respectively.

\subsection{Animal manure}

In case of China, human, pig, cattle and chicken are considered to estimate the energy potential of animal manure. The waste of sheep, horses and ducks is ignored because their excrement is dispersed and difficult to collect. Cattle, buffalo, sheep and goat, pigs and poultry are considered to estimate the energy from animal manure in India. In case of Philippines, six types of animals were taken into consideration namely: hog, cattle, chicken, duck, carabao (buffalo) and goat as these are widely raised not just in the backyard level but in commercial scale as well. For the present estimation only cattle, buffalo, chicken and goat are considered, in addition to human beings in Sri
Lanka. Cattle, buffaloes, swine, chicken, duck and elephant are considered to estimate the energy potential in case of Thailand. Energy potential of animal manure in 2010 is estimated to be 2095, 374, 4.9, 6.5 and 13 PJ for China, India, Philippines, Sri Lank and Thailand, respectively.

\subsection{Municipal solid wastes}

In China, with the acceleration of urbanization, the MSW generation is rising at about $8-10 \%$ per year. As per a survey conducted in 10 Chinese cities, the MSW output in China is in the range of 0.66-2.62 $\mathrm{kg} \mathrm{capita}^{-1} \mathrm{day}^{-1}$. In India, the total MSW generated is $23.5 \mathrm{Mtyr}^{-1}$; based on the MSW collected in 5 large cities, the average MSW landfilled is about $85 \%$. In case of Philippines, the average per capita MSW generation is assumed as $0.544 \mathrm{~kg} \mathrm{day}^{-1}$. In the present analysis, in case of Sri Lanka, it is assumed that only MSW generated in urban sector could be collected for landfill and the generation rate in urban sector is taken as $0.75 \mathrm{~kg}$ capita $^{-1}$ day $^{-1}$; the fraction of MSW landfilled in 1997 is taken as $80 \%$. In Thailand, the MSW generation rate varies form 0.93 to $1.55 \mathrm{~kg} \mathrm{head}^{-1} \mathrm{day}^{-1}$; the fraction of MSW landfilled varies from 0.74 to 0.91 . Energy potential of MSW in 2010 is estimated to be 91, 219, 47, 4.8 and 21.3 PJ for China, India, Philippines, Sri Lanka and Thailand, respectively.

\subsection{Potential of fuelwood release through efficiency improvement and substitution by other fuels}

In China, total energy potential of fuelwood release through efficiency improvement has been estimated for cooking stove, oven, boiler, furnace, and kiln. Potential of fuelwood release through efficiency improvement in cooking and industrial sector has been studied in India. In case of Philippines, the potential of biomass release through efficiency improvement is considered in domestic sector and industrial sector; in the industrial sector the main devices selected for efficiency improvements are bakery ovens, wood fired boilers and furnaces. In case of Sri Lanka, potential of fuelwood release in household-, industrial-, and commercial-sector are considered. 


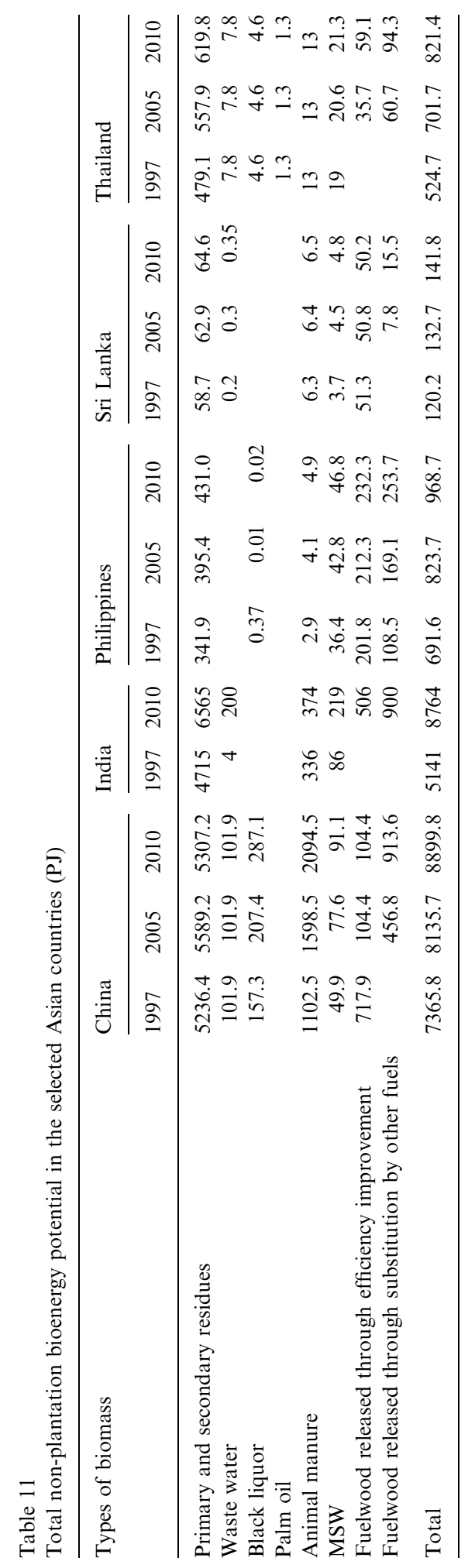

In case of Thailand, fuelwood release potential is mainly considered in household cooking and industries. Potential of fuelwood release through efficiency improvement in 2010 is estimated to be 104, 506, 232, 50 and $59 \mathrm{PJ}$ for China, India, Philippines, Sri Lanka and Thailand, respectively.

Potential of fuelwood release through substitution by other fuels in 2010 is estimated to be 914 , 900, 254, 16 and 94 PJ for China, India, Philippines, Sri Lank and Thailand, respectively.

\section{Concluding remarks}

As shown in Table 11, large amounts of nonplantation biomass resources are available for modern energy applications in the selected Asian countries. The estimated sustainable non-plantation bioenergy potential in 2010 in China, India, Philippines, Sri Lanka and Thailand is about 8.90, $8.77,0.97,0.14$ and $0.82 \mathrm{EJ}$, respectively. The potential is estimated to be about $17,45,34,33$, and $14 \%$ of the projected total energy consumption in 2010 respectively in these countries. Primary and secondary residues are the major non-plantation biomass energy sources accounting about $60,75,45,46$, and $75 \%$ of the total nonplantation biomass energy sources in China, India, Philippines, Sri Lanka, and Thailand in 2010, respectively. Fuelwood saving potential through substitution by other fuels is estimated to be about $10 \%$ of the total non-plantation biomass energy potential in 2010 in the selected countries except Philippines; in Philippines the saving potential is $26 \%$ of the total. The fuelwood saved through efficiency improvement of the biomass energy systems in present applications can potentially play a significant role in meeting energy demands in other applications in Philippines and Sri Lanka. The estimated fuelwood saving potential is about 24 and 35 of the total non-plantation biomass energy in Philippines and Sri Lanka respectively.

\section{Acknowledgement}

The authors thank the Swedish International Development Cooperation Agency (SIDA) for the 
support provided for this work under the Asian Regional Research Programme in Energy, Environment and Climate (ARRPEEC).

\section{References}

[1] Bhattacharya SC, Arul Joe M, Zahed Kandhekar, Abdul Salam P, Shrestha RM. Greenhouse-gas emission mitigation from the use of agricultural residues: the case of rice husk. Energy 1999;24:43-59.

[2] Bhattacharya SC, Singamsetti VM, Abdul Salam P. Assessment of bioenergy potential in Asia. Presented in the Asian seminar on fuel cell technology for rural electrification. Coimbatore, India, April 25-26, 1996.

[3] Lettinga G, Hulshoff LW. Anaerobic reactor technology. International course on anaerobic wastewater treatment. Wageningen Agricultural University. Netherlands, June 26-August 7, 1991.

[4] IPCC. Revised 1996 IPCC guidelines for national greenhouse gas inventories: reference manual, vol. 3. Intergovernmental Panel on Climate Change; 1996.

[5] Hack PJFM. The UASB reactor treating paper and board mill effluent. In: Wise L, editor. Global bioconversions 1987;1:145-54.

[6] Shick WK, Alan YL. High rate anaerobic treatment of industrial waste waters. In: Wise L., editor. Global bioconversions 1987;3:41-80.

[7] Grace TH. Overview of kraft recovery. In: Pulp and paper manufacture. Alkaline pulping 1989;5:473-6.
[8] Grace TH. Black liquor evaporation. In: Pulp and paper manufacture. Alkaline pulping 1989;5:477-529.

[9] Mannisto H, Mannisto E. Why energy conservation? In: TAPPI proceedings 1997, Engineering and papermakers: forming bonds for better papermaking, Book 1. TAPPI press, Atlanta, U.S.A; 1997: p. 1-7.

[10] Bhattacharya SC, Thomas JM, Abdul Salam P. Greenhouse gas emissions and the mitigation potential of using animal wastes in Asia. Energy 1997;22: 1079-85.

[11] USOTA. Facing America's trash what next for municipal solid waste? Congress of the US office of technology assessment, OTA-0-42, Washington DC: US Government Printing Office-October 1989.

[12] Quon. Selected readings in quantitative urban analysis. In: Samuel J, Bernstein A, Giles Mellon W, editors. Oxford: Pergamon press; 1966.

[13] King BF, Murphy RC. Survey to estimate residential solid waste generation. Journal of Environmental Engineering 1996.

[14] Homez ER. Greenhouse gas emission from non-agricultural residues and processes. Thesis no. ET-94-29. Asian Institute of Technology, Bangkok; 1994.

[15] BSR. Bioenergy systems report - prospects in developing countries for energy from urban wastes. Office of Energy, US Agency for International Development; 1988.

[16] Bhattacharya SC, Attalage RA, Leon MA, Amur GQ, Abdul Salam P, Thanawat C. Potential of biomass fuel conservation in selected Asian countries. Energy conservation \& Management 1999;40:1141-62. 